\title{
Effect of salinity on spatial distribution and cell volume regulation in two sibling species of Marenzelleria (Polychaeta: Spionidae)
}

\author{
Miriam Blank, Ralf Bastrop*, Matthias Röhner, Karl Jürss \\ University of Rostock, Department of Biology, Institute of Biodiversity Research, Albert-Einstein-Strasse 3, \\ 18051 Rostock, Germany
}

\begin{abstract}
Marenzelleria sibling species Types I and II are characteristically distributed within the salinity gradient of the Elbe estuary. For the first time $\mathrm{F}_{1}$-hybrids between the 2 Marenzelleria species were found. Type I inhabits mainly the isoosmotic/hyperosmotic range, while Type II and the $\mathrm{F}_{1}$-hybrids prevail in the hypoosmotic range. A sympatric occurrence could be inferred in salinity ranges from 3.3 to 12.3 ppt. Marenzelleria sibling species Type II has been found for the first time in the North Sea (Elbe estuary). The influence of salinity on the distribution of Marenzelleria spp. was examined by laboratory experiments. In a time-course experiment with salinity changes from 10 to $25 \mathrm{ppt}$ and from 25 to $10 \mathrm{ppt}$, respectively, enzyme activities and free amino acids were determined. The activities of alanine aminotransferase, aspartate aminotransferase, and glutamate dehydrogenase were always higher in Type I than in Type II. A salinity increase from 10 to 25 ppt resulted in a faster increase of the concentrations of D,L-alanine, glycine, serine, glutamate and threonine in Type I. The biochemical results showed that the capacity of cell volume regulation could be involved in the different spatial distributions of the 2 sibling species.
\end{abstract}

KEY WORDS: Marenzelleria spp. $\cdot$ Sibling species $\cdot$ Hybrids $\cdot$ Cell volume regulation $\cdot$ Free amino acids $\cdot$ D-alanine $\cdot$ Enzyme activities $\cdot$ Allozyme electrophoresis

\section{INTRODUCTION}

Salinity is an important factor for the spatial distribution of animals living in brackish water (Kolding 1985, Arndt 1989), although factors such as food availability, substrate type, predation and water depth have to be taken into consideration as well (Webb et al. 1997). In this context, biological invasions are of particular interest. Successful colonisation mainly depends on the genotype of the immigrant, as well as on specific characteristics (e.g. salinity) of the new habitat.

If sibling species immigrate at roughly the same time, they should - according to evolutionary adaptation access separate habitats (niches). However, when individuals of such sibling species occur in overlapping areas, they may possibly even hybridise, although hybridisation may not be inherent in their area of origin.
Abundant populations of Marenzelleria spp. were reported for the first time in Europe in the North Sea during the late 1970s (Elliott \& Kingston 1987) and then in the Baltic Sea in 1985 (Bick \& Burckhardt 1989). The most probable mode of immigration was via the ballast water of ships from the Atlantic coast of North America to Europe. Originally, it was assumed that a single non-indigenous species, M. viridis (Verrill, 1873), had invaded European waters (Essink \& Kleef 1993, Bastrop et al. 1997). Genetic analysis by means of starch gel electrophoresis of allozymes and sequencing of a segment of mitochondrial 16S rDNA showed later that 2 different, sibling species of Marenzelleria were present in Europe. Marenzelleria Type I (M. cf. wireni) is found in the North Sea only, whereas Type II ( $M$. cf. viridis) exists in both the Baltic Sea and, probably, the North Sea, namely in the Elbe estuary (Bastrop et al. 
1995, 1997, 1998, Röhner et al. 1996a,b, Bick \& Zettler 1997). The North Sea worms of Type I correspond to the Type I specimens found in coastal waters between Nova Scotia (Canada) and Cape Henlopen (Delaware, USA), while Marenzelleria Type II from the Baltic Sea corresponds to Marenzelleria Type II worms from the Arctic (Tuktoyaktuk Harbor, Northwest Territories, Canada), New Hampshire and coastal waters between Chesapeake Bay southward to the Ogechee River in Georgia, USA (Röhner et al. 1996b, Bastrop et al. 1997, 1998).

The genetic studies showed clearly that at about the same time 2 sibling species of the genus Marenzelleria were introduced into the North and the Baltic Sea, respectively (Bastrop et al. 1998).

Marenzelleria Type I appears to colonise habitats with a higher or fluctuating salinities. Both sibling species are hyperosmoregulators/osmoconformers, like Nereis diversicolor (Hohendorf 1963, Bastrop et al. 1997). The osmolality of the coelomic fluid after acclimation to various salinities between 0.25 and $18 \mathrm{ppt}$ is the same for both sibling species (Bastrop et al. 1997).

The aim of the present research was to unravel the spatial distribution and differences in cell vollume regulation between the sibling species in the Elbe estuary, in order to derive hypotheses related to interaction between genotype and habitat. Occurrences of both Marenzelleria species in the Elbe estuary could be regarded as a natural experiment to establish the influence of salinity. By allozyme electrophoresis we analysed for the first time the occurrence of Marenzelleria Type II and were interested in the following questions: (1) How are the sibling species distributed within the salinity gradient of the Elbe River estuary? (2) Does hybridisation occur?

The field study has proven that both species of Marenzelleria can be found in the Elbe estuary (see 'Results') and led to the hypothesis that cell vollume regulation in the osmoconformal range ( $>10 \mathrm{ppt}$ ) may be responsible for different distribution patterns of the species. To test this hypothesis laboratory experiments have been conducted.

As an indicator for cell vollume regulation, the concentration of free amino acids (FAAs) was determined during salinity acclimation for both sibling species. The adjustment of intracellular FAA concentrations plays an important role in acclimation to salinity changes in polychaetes (Oglesby 1978) and other marine invertebrates (Gilles 1975, 1979, Henry 1995).

When osmoconformers are exposed to changing salinity regimes, they will gain or lose water along the osmotic gradient. High intracellular FAA concentrations counterbalance high inorganic ion concentrations in the extracellular fluid of polychaetes exposed to elevated salinities (Oglesby 1978, Reitze et al. 1989). In
Marenzelleria spp. only a few non-essential amino acids such as alanine and glycine are major contributors to the response (Schiedek 1999).

Alanine aminotransferase (GPT) catalyses the synthesis of L-alanine from glutamate and pyruvate (Stryer 1996). According to Jürss et al. (1999), this enzyme has a higher level of activity in Marenzelleria Type I compared to Marenzelleria Type II. Therefore, Type I is expected to react with a faster increase in the alanine level towards hyperosmotic stress. To evaluate this hypothesis, a time-course experiment was carried out using the salinity regime known from studies at Stn 5, which is characterised by a fluctuating salinity and an almost complete disappearance of Marenzelleria Type II, in comparison to Stn 4, where both species occur sympatrically. FAA levels, activities of 3 enzymes of amino acid metabolism, i.e. alanine aminotransferase, aspartate aminotransferase (AAT) and glutamate dehydrogenase (GDH), as well as 2 enzymes of the energy metabolism (citrate synthase [CS] and octopine dehydrogenase [ODH]) were measured. The synthesis of citrate from oxaloacetate and acetyl coenzyme A by the key enzyme CS is an important control point of citric acid cycle (Stryer 1996). Therefore, CS was used as an indicator for aerobic metabolism. For pelagic chaetognaths, nemerteans and annelids (Polychaeta), an excellent correlation between the metabolic rate $\left(\mathrm{O}_{2}\right.$ consumption) and CS activities has been found (Thuesen \& Childress 1993a,b).

For some invertebrates (e.g. polychaetes), it is known that the opine dehydrogenases function along with or replace lactate dehydrogenase (LDH) during anaerobic metabolism (Livingstone 1991, Thuesen \& Childress 1993b). For example, in the polychaete genus Tomopteris high lactate dehydrogenase as well as very low octopine dehydrogenase activities were found (Thuesen \& Childress 1993b). Surprisingly, in Marenzelleria spp. lactate, strombine and alanopine dehydrogenase showed only low activities, while high activities of ODH could be detected. Furthermore, octopine is the only measurable end product of cytosolic glycolysis in Marenzelleria spp. (Schiedek 1997a,b, Schiedek et al. 1997). Therefore, ODH was taken as an indicator for anaerobic metabolism.

\section{MATERIALS AND METHODS}

Starch gel electrophoresis of allozymes. Worms were collected from the Elbe estuary in May 1997 (Fig. 1) and from the Ringkobing Fjord (RkF) and Darss-Zingst Bodden Chain (DZBC) in July 1997. Data concerning the last 2 populations are given in Jürss et al. (1999). 


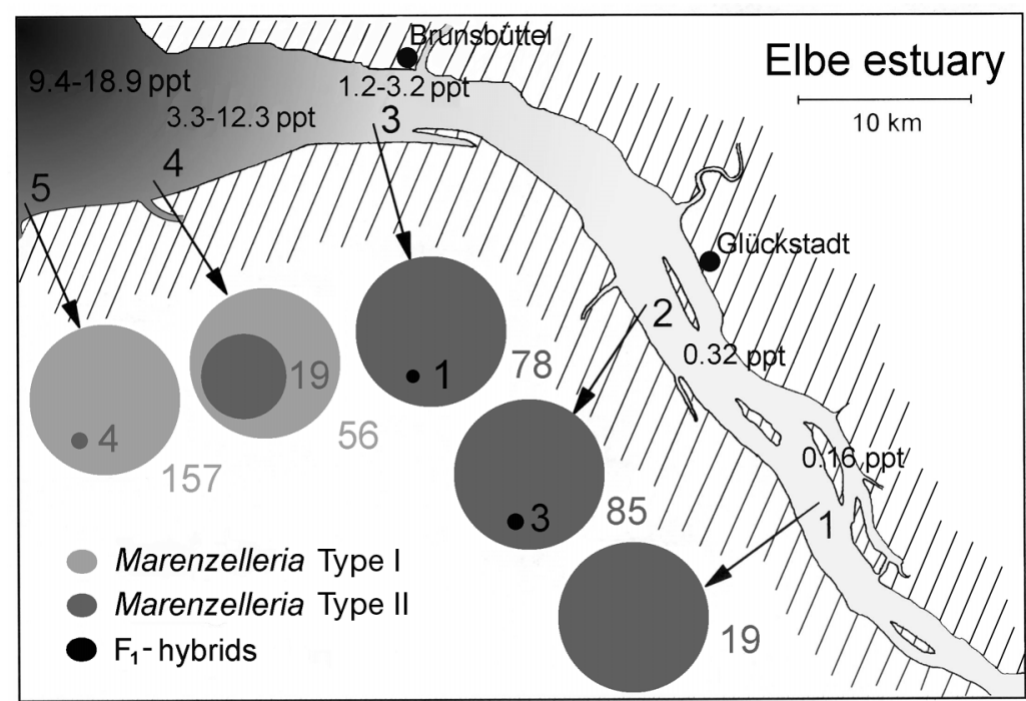

Fig. 1. Marenzelleria spp. Salinity-dependent distribution in the Elbe River estuary (Germany). Sampling locations and maximum salinity fluctuations during low and high tide on 20 and 21 May 1997 are indicated (data obtained from: www.cux.wsd-nord.de/htm/start.asp). Stn 1: Twielefleth; Stn 2: Wischhafen; Stn 3: Brunsbüttel; Stn 4: Neufelder Reede; Stn 5: Altenbrucher Bogen (green buoy 41). Circles and numbers next to each circle show the number of species investigated at the sampling location

sand. Incidences of mortality observed during the first days after sampling were attributed to stress during sampling and transport. No mortality was observed during the course of the experiment.

Prior to the experiments, the worms were acclimated for $51 \mathrm{~d}$ to $10^{\circ} \mathrm{C}$ and $10 \mathrm{ppt}$ salinity and a photo period of $12 \mathrm{~h}$ light/12 $\mathrm{h}$ dark. The acclimation salinity corresponds to the salinity at the beginning of isoosmia for both species (Bastrop et al. 1997). The acclimation temperature was chosen because sexual maturing in both types is less rapid at $10^{\circ} \mathrm{C}$ (Bochert 1996). The worms were fed regularly with cultured Chlorella sp. until 1 wk before the experiments commenced.

After the period of acclimation, the animals were transferred to 25 ppt salinity. In order to reduce the risk of mortality caused by stress, water was sucked off with a flexible tube to leave the sediment undisturbed. Aerated artificial seawater of 25 ppt was then carefully filled in. For each time point, 3 aquaria were set up per species. Additionally, 3 further aquaria

Sediment samples were taken by a Van Veen grab (Elbe estuary) or by means of a corer at the other 2 sampling sites. Specimens were separated by sieving and immediately frozen in liquid nitrogen. The numbers of worms investigated for each species are shown in Fig. 1.

A total of 8 enzymes representing 10 loci were analysed: isocitrate dehydrogenase (IDH, EC 1.1.1.42), aspartate aminotransferase (AAT, EC 2.6.1.1), octopine dehydrogenase $(\mathrm{ODH}, \mathrm{EC}$ 1.5.1.11), malate dehydrogenase (MDH, EC 1.1.1.37), glycerol-3-phosphate dehydrogenase (G3PDH, EC 1.1.1.8), D-glyceraldehyde-3-phosphate dehydrogenase (GAPDH, EC 1.2.1.12), arginine kinase (APK, EC 2.7.3.3) and adenylate kinase (AK, EC 2.7.4.3). The methods used for allozyme electrophoresis and statistical evaluation are described in Bastrop et al. (1995), Röhner et al. (1996a,b) and Jürss et al. (1999).

Expt 1. Specimens of Marenzelleria spp. were collected in a brackish estuary in the North Sea (Type $\mathrm{I}_{i}$ Ringkobing Fjord, Denmark) and the Baltic Sea (Type II; Bodstedter Bodden, Darss-Zingst Bodden Chain) (Table 1). Sediment samples were taken by the means of a corer and subsequent sieving. Individuals were transported alive to the laboratory.

In each case, 20 specimens were kept in plastic aquaria containing aerated artificial seawater (Red Sea Salt, Coral Reef Fishpharm Ltd, Israel). The bases of the aquaria had been covered with $2 \mathrm{~cm}$ of washed per species were prepared as control aquaria with 10 ppt. To ensure the same conditions in both test and control aquaria, the water of the latter was changed as well.

After 3, 6, 12, 24, 72, 144, 288, $672 \mathrm{~h}$, respectively, the worms of all 3 aquaria for each species were taken from the aquaria and frozen in liquid nitrogen until further analysis.

It was assumed that the polychaetes had reached a new steady state after $672 \mathrm{~h}$ (28 d). After $672 \mathrm{~h}$, the salinity within the aquaria was changed from $25 \mathrm{ppt}$ back to $10 \mathrm{ppt}$ ( $672 \mathrm{~h}$ was considered a new reference value). At 12, 24, 48 and $96 \mathrm{~h}$ after changing the water, worms were taken from the aquaria and frozen.

The average weight of specimens of both types was almost equal (Type I: $0.0359 \mathrm{~g}$ [0.0113 g to $0.1301 \mathrm{~g}]$; Type II: $0.0436 \mathrm{~g}$ [0.0123 g to $0.0926 \mathrm{~g}]$ ).

Table 1. Marenzelleria spp. Salinity and temperature regimes at the sampling locations (RkF: Ringkobing Fjord; DZBC: Darss-Zingst Bodden Chain)

\begin{tabular}{|ccccc|}
\hline & $\begin{array}{c}\text { Sampling } \\
\text { locations }\end{array}$ & Date & $\begin{array}{c}\text { Salinity } \\
\text { (ppt) }\end{array}$ & $\begin{array}{c}\text { Temperature } \\
\left({ }^{\circ} \mathrm{C}\right)\end{array}$ \\
\hline Expt 1 & RkF & Jul 2001 & 11.9 & 22.0 \\
& DZBC & Jul 2001 & 4.6 & 27.0 \\
Expt 2 & RkF & Sep 2002 & 11.4 & 24.5 \\
& DZBC & Aug 2002 & 3.3 & 19.0 \\
\hline
\end{tabular}


Free amino acids: Frozen worms were cut into 4 equal pieces. Piece 1 (head end) and Piece 3 were homogenised in ice-cold, $1 \mathrm{M}$ perchloric acid $(2 \times 30 \mathrm{~s})$ using an ultrasonic homogeniser (Bandelin HD 60). After centrifugation at $24000 \times g$ for $10 \mathrm{~min}$ at $0^{\circ} \mathrm{C}$, the supernatant was removed and neutralised with $5 \mathrm{M}$ $\mathrm{K}_{2} \mathrm{CO}_{3}$. After incubation on ice for $30 \mathrm{~min}$, the precipitated $\mathrm{KClO}_{4}$ was removed by means of centrifugation (20 min, $24000 \times g, 0^{\circ} \mathrm{C}$ ). The supernatant was frozen at $-20^{\circ} \mathrm{C}$ until analysis.

In order to determine the dry weight, Pieces 2 and 4 (tail end) were dried at $60^{\circ} \mathrm{C}$ for $24 \mathrm{~h}$ in a heating oven (Heraeus).

For analysis of the FAAs, a Shimadzu-HPLC system with a Grom column (Germany) was used. Spectrophotometric detection of amino acids was performed at $570 \mathrm{~nm}$, or at $440 \mathrm{~nm}$ in the case of proline.

Using an external standard, identification was performed with the Shimadzu-HPLC software. For each sample, 3, 5 and $10 \mu \mathrm{l}$ of supernatant were analysed and averaged.

The content of the amino acids D,L-alanine (D,L-ala), glycine (gly), proline (pro), histidine (his), arginine (arg), aspartate (asp), serine (ser), threonine (thr) and glutamate (glu) is expressed as $\mu_{\mathrm{mol} \mathrm{g}}{ }^{-1}$ dry wt.

Enzyme activities: The preparation of the worm homogenates and the measurement of the activities of the enzymes AAT, EC 2.6.1.1, GPT, EC 2.6.1.2, ODH, EC 1.5.1.11 and CS, EC 4.1.3.7 were carried out according to Jürss et al. (1999). Glutamate dehydrogenase (GDH, EC 1.4.1.4) was determined according to Peng et al. (1994). Total protein concentrations were determined with the bicinchoninic acid kit (Sigma), with bovine serum albumin as standard. The chemicals used were purchased from Sigma, AppliChem or Roche Diagnostics.

Expt 2 (D,L-ala). The specimens for the second experiment were collected from Ringkobing Fjord (Denmark) and from Bodstedter Bodden (DZBC, Ger-

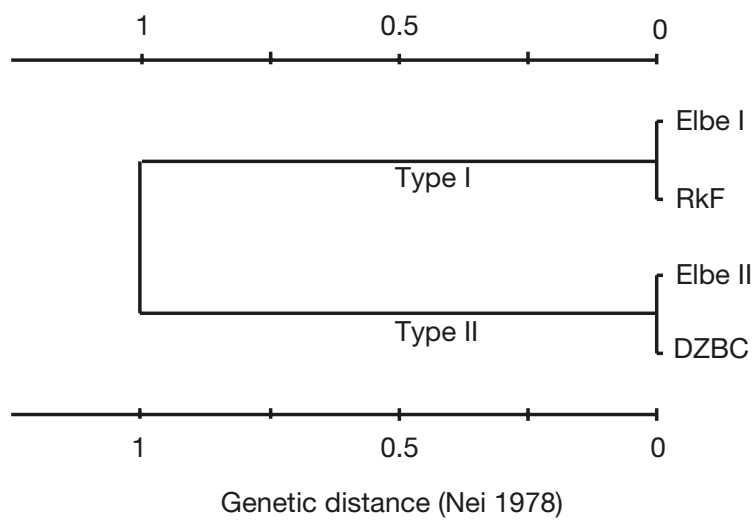

Fig. 2. Marenzelleria spp. UPGMA tree of Nei's (1972) genetic distance many; Table 1) and were treated as described for Expt 1.

After $36 \mathrm{~h}$ at $25 \mathrm{ppt}, 5$ worms of each species were taken out and frozen in liquid nitrogen.

Homogenates were analysed using optical tests for D-ala and L-ala (Graßl \& Supp 1985, Williamson 1985) or HPLC (Agilent series 1100; column RP C18, Knauer). D-ala and L-ala were separated according to Nimura \& Kinoshita (1986) and Görs (2002). As prelabelling reagents, N-acetyl-L-cysteine and o-phthalaldehyde were used.

Statistics. All data are presented as means \pm standard error (SE). Statistical significance was tested only within each species. Differences between means were tested for significance by Student's $t$-test in the case of equal variances, or by Welsh's $t$-test otherwise. Statistical significance was accepted at $\mathrm{p}<0.05$.

\section{RESULTS}

\section{Distribution of species and detection of hybrids}

The genetic analysis has established for the first time incidences of both Marenzelleria species (Types I and II) in the North Sea, namely in the Elbe estuary. Both species are characteristically distributed along the salinity gradient of the Elbe estuary (Fig. 1). Marenzelleria Type I inhabits the osmoconformal range, while Marenzelleria Type II prefers the oligohaline area (hyperosmotic regulation). At Stns 4 and 5, both species appear sympatrically. The populations sampled in the Elbe estuary were compared with those from the RkF and the DZBC. The Marenzelleria Type I population from the Elbe and the population from RkF showed a genetic distance of $D=0.001$, while a genetic distance of $D=0.000$ was established between the Marenzelleria Type II population from the Elbe and that from the DZBC. This proves that they are virtually identical populations of Type I or Type II (Fig. 2). Based on these similarities and due to sampling difficulties, we alternatively used Marenzelleria samples from RkF and DZBC for laboratory experiments.

Apart from establishing the occurrence of both Marenzelleria sibling species in the Elbe estuary, incidences of hybridisation have been found for the first time. Fig. 3a shows the electrozymogram of $I D H$ from worms of Stn 1 (Twielenfleet) and Stn 4 (Neufelder Reede). Like all other loci examined in this paper, i.e. $M D H-I I, G A P D H, A K$ and $A P K, I D H$ represents a diagnostic locus (Ayala \& Powell 1972), which allows $100 \%$ classification of the specimens to either Marenzelleria Type I or Type II (Bastrop et al. 1995, 1997, Röhner et al. 1996a,b). Fig. 3b shows the electrozymogram of IDH for Type I and II, as well as for a hybrid. 


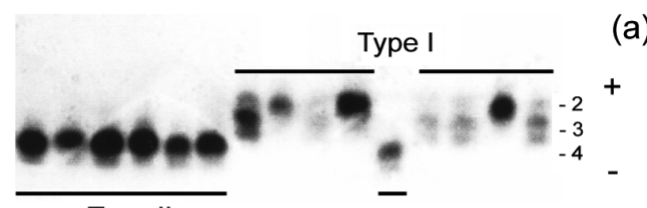

Type II
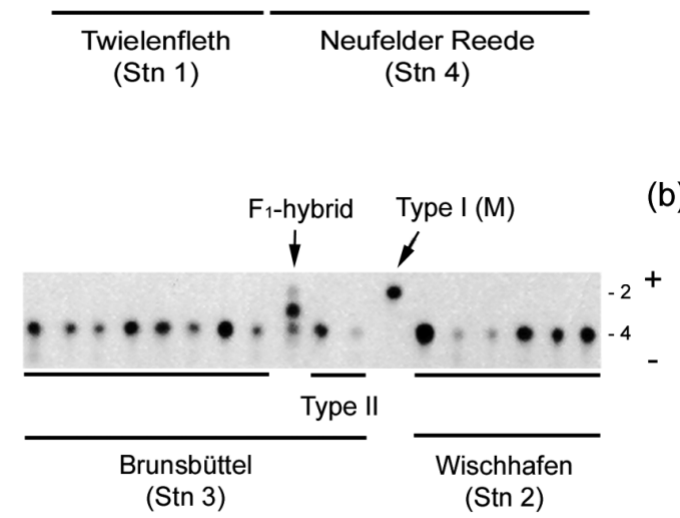

Fig. 3. Marenzelleria spp. (a) Zymogram of $I D H^{*}$; sampling locations and genetic Types I and II are indicated. Alleles denoted by 2, 3 and 4. (b) Zymogram of $I D H^{*}$; sampling locations, genetic Types I, II and an $\mathrm{F}_{1}$-hybrid are indicated.

Alleles denoted by 2 and 4 . M: individual used as marker

All data for the diagnostic loci indicated the presence of $3 \mathrm{~F}_{1}$-hybrids at Stn 2 and $1 \mathrm{~F}_{1}$-hybrid at Stn 3 (Fig. 1).

The genotype frequencies of the investigated samples, parameters characterising genetic variation and the coefficients of genetic identity and genetic distances of the populations are presented in Table 3 \& Appendix 1.

\section{Enzyme activities}

Fig. 4 shows the results of the enzyme activity comparisons of the sibling species (Table 2) after long-term
Table 2. Marenzelleria spp. Expt 1. Ratio of enzyme activities after acclimation $\left(10 \mathrm{ppt} / 10^{\circ} \mathrm{C}_{\mathrm{i}}\right.$ control $)$ and at new steady state $(25 \mathrm{ppt} / 672 \mathrm{~h}) . V_{\max }$ ratio: maximal rate of an enzyme under saturating conditions

\begin{tabular}{|lccc|}
\hline Enzyme & Days & $\begin{array}{c}\text { Salinity } \\
\text { (ppt) }\end{array}$ & $\begin{array}{c}V_{\text {max }} \text { ratio } \\
\text { RkF Type I/DZBC Type II }\end{array}$ \\
\hline CS & 51 & 10 & 1.06 \\
& 28 & 25 & 1.33 \\
ODH & 51 & 10 & 1.08 \\
& 28 & 25 & 1.16 \\
GDH & 51 & 10 & 1.49 \\
& 28 & 25 & 1.81 \\
AAT & 51 & 10 & 1.37 \\
& 28 & 25 & 1.45 \\
GPT & 51 & 10 & 1.74 \\
& 28 & 25 & 1.96 \\
\hline
\end{tabular}

acclimation $(51 \mathrm{~d}$ at $10 \mathrm{ppt}=10 \mathrm{ppt} / 0 \mathrm{~h} ; 28 \mathrm{~d}$ at $25 \mathrm{ppt}$ $=25 \mathrm{ppt} / 672 \mathrm{~h}$ ). After acclimation to an isoosmotic and hyperosmotic environment Marenzelleria Type I shows noticeably higher activity levels of enzymes involved in amino acid metabolism than Marenzelleria Type II. With regard to CS and ODH, such quantitative differences do not exist. Apart from the CS of Marenzelleria Type I, no salinity acclimation can be observed on an enzyme level. Thus, the enzymes involved in amino acid metabolism exhibit a constitutively higher level in Type I than in Type II.

\section{Free amino acids}

After long-term acclimation (51 d at 10 ppt; $28 \mathrm{~d}$ at $25 \mathrm{ppt}$ ), the 2 sibling species showed an almost identical pool of total amino acids (Fig. 5). Under these conditions, the concentration of gly, ser and his was species specific. The amino acid gly was 1.53 - to 1.78-fold higher in Marenzelleria Type I, while in Type II ser and

Table 3. Marenzelleria spp. Genetic variability at 10 loci in all populations $( \pm \mathrm{SE})$. Expected heterozygosity according to Nei's (1978) unbiased estimate

\begin{tabular}{|c|c|c|c|c|c|c|}
\hline \multirow[t]{2}{*}{ Population } & \multirow[t]{2}{*}{ Type } & \multirow{2}{*}{$\begin{array}{c}\text { Average sample } \\
\text { size per locus }\end{array}$} & \multirow{2}{*}{$\begin{array}{l}\text { Average no. of } \\
\text { alleles per locus }\end{array}$} & \multirow{2}{*}{$\begin{array}{c}\text { Percent poly- } \\
\text { morphic loci } P(0.95)\end{array}$} & \multicolumn{2}{|c|}{ Average heterozygosity } \\
\hline & & & & & Observed & Expected \\
\hline $\begin{array}{l}\text { Elbe, } \\
\text { North Sea }\end{array}$ & I & $\begin{array}{c}199.2 \\
(9.0)\end{array}$ & $\begin{array}{c}1.6 \\
(0.2)\end{array}$ & $\begin{array}{c}30.0 \\
(0.060)\end{array}$ & $\begin{array}{c}0.121 \\
(0.059)\end{array}$ & 0.124 \\
\hline $\begin{array}{l}\text { Ringkobing Fjord, } \\
\text { North Sea }\end{array}$ & I & $\begin{array}{l}69.8 \\
(0.1)\end{array}$ & $\begin{array}{l}1.7 \\
(0.2)\end{array}$ & $\begin{array}{c}30.0 \\
(0.066)\end{array}$ & $\begin{array}{c}0.135 \\
(0.067)\end{array}$ & 0.142 \\
\hline $\begin{array}{l}\text { Elbe, } \\
\text { North Sea }\end{array}$ & $\begin{array}{c}\text { II } \\
(6.9)\end{array}$ & $\begin{array}{c}186.4 \\
(0.5)\end{array}$ & $\begin{array}{c}2.6 \\
(0.042)\end{array}$ & $\begin{array}{c}10.0 \\
(0.039)\end{array}$ & 0.064 & 0.060 \\
\hline $\begin{array}{l}\text { Darss-Zingst } \\
\text { Bodden Chain, } \\
\text { Baltic Sea }\end{array}$ & $\begin{array}{c}\text { II } \\
(0.0)\end{array}$ & $\begin{array}{l}70.0 \\
(0.4)\end{array}$ & $\begin{array}{c}1.9 \\
(0.035)\end{array}$ & $\begin{array}{c}20.0 \\
(0.041)\end{array}$ & 0.059 & 0.066 \\
\hline
\end{tabular}



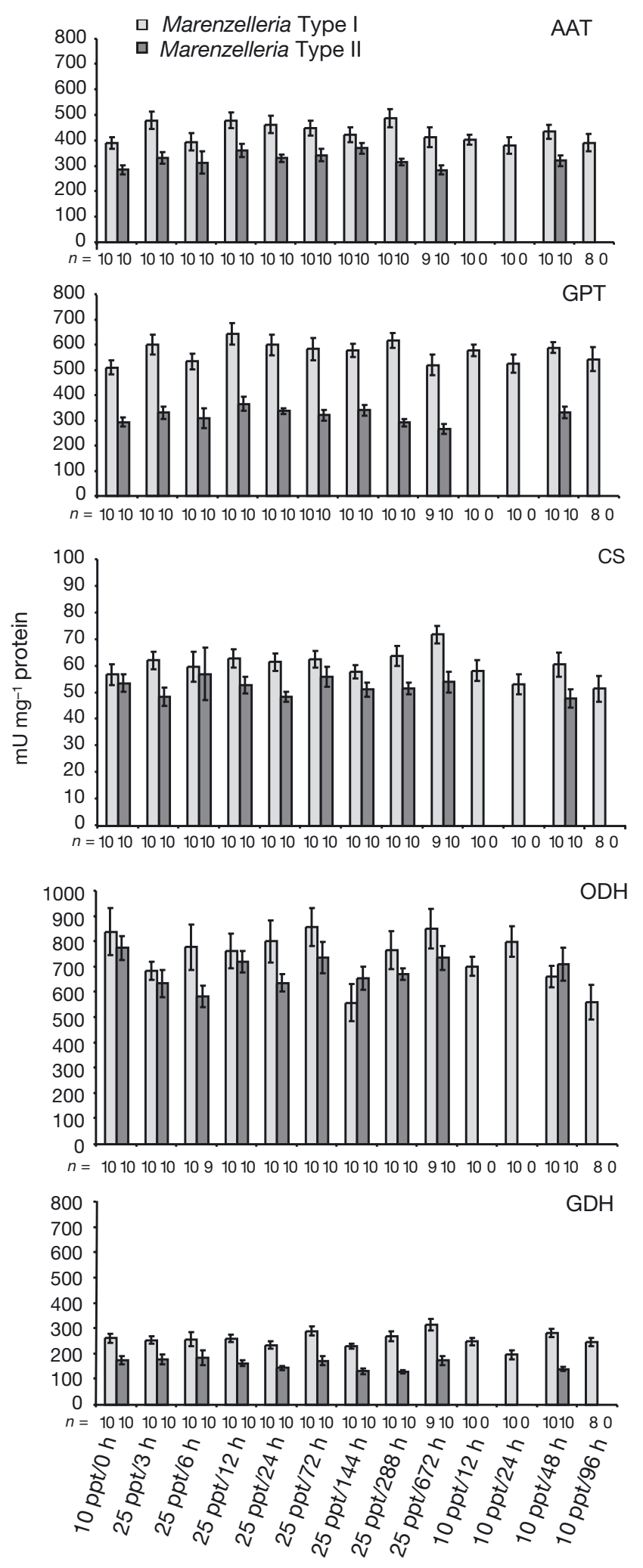

Fig. 4. Marenzelleria spp. Expt 1. enzyme activities (mU mg ${ }^{-1}$ protein \pm SE) at different points in time during the timecourse experiment. Number of specimens analysed is indicated under each column his showed 2.49- to 1.71-fold and 3.51- to 2.07-fold higher concentrations, respectively (Fig. 6). Arg was the only amino acid examined that is not influenced by external salinity. For both Marenzelleria species, concentrations of all other FAAs were significantly altered during the time after salinity change. In both species, concentrations of D,L-ala and pro rose fastest with an increase in salinity from 10 to 25 ppt. D,L-ala, gly and pro showed the highest increase in concentration during salinity acclimation. In the initial phase of hyperosmotic stress, D,L-ala was most important for both Marenzelleria species to adjust the intracellular osmotic concentration. The most striking difference between the sibling species was found in the time course of D,L-ala, 3 and $6 \mathrm{~h}$ after changing salinity, the D,L-ala level of Type I in 25 ppt rose significantly by 1.33- and 1.95-fold, respectively. For Type II, the first significant rise in D,L-ala occurred only after $6 \mathrm{~h}$ (1.61fold). The level of other FAAs also increased faster and to a higher extent in Marenzelleria Type I compared to control specimens (Fig. 6).

Within the first $24 \mathrm{~h}$ in $25 \mathrm{ppt}$, D,L-ala, gly, ser, glu and thr concentrations increased much faster in Marenzelleria Type I than in Type II (Fig. 6). Therefore, the total amino acid pool of Type I in 25 ppt was significantly enhanced already after $6 \mathrm{~h}$ in worms compared to control specimens in 10 ppt. For Marenzelleria Type II, the same effect was not observed until after 24 to $72 \mathrm{~h}$. When specimens were kept at 25 ppt for $24 \mathrm{~h}$, the total FAA pool both Type I and Type II increased 1.97-and 1.28-fold, respectively.

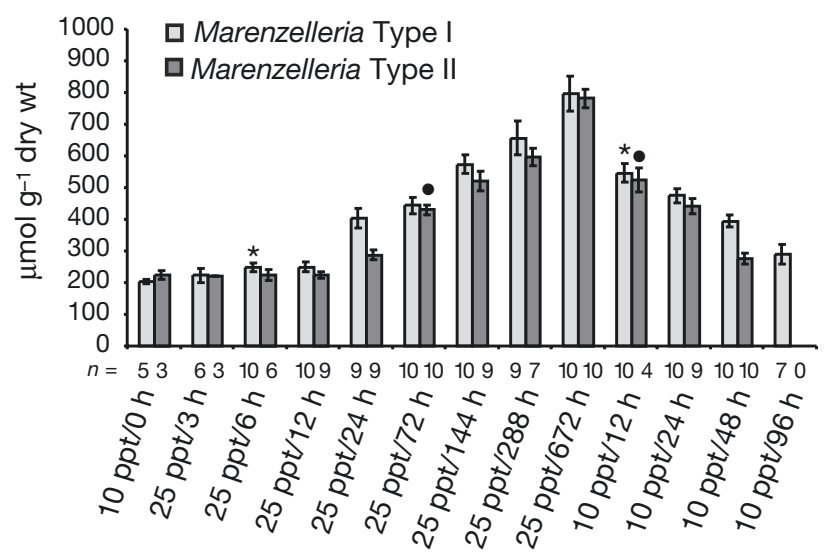

Fig. 5. Marenzelleria spp. Expt 1. Salinity-dependent change of the total free amino acid (FAA) pool (D,L-ala, gly, pro, his, arg, asp, ser, thr, glu) during the time-course experiment. Data are mean $\left(\mu \mathrm{mol} \mathrm{g}{ }^{-1}\right.$ dry $\left.w t\right) \pm S E$ values. Asterisks indicate first significant increase and decrease compared to the control $(10 \mathrm{ppt} / 0 \mathrm{~h})$ and steady state $(25 \mathrm{ppt} / 672 \mathrm{~h})$ in Type I. Dots indicate first significant increase and decrease in Type II. Number of specimens analysed is indicated under each column 

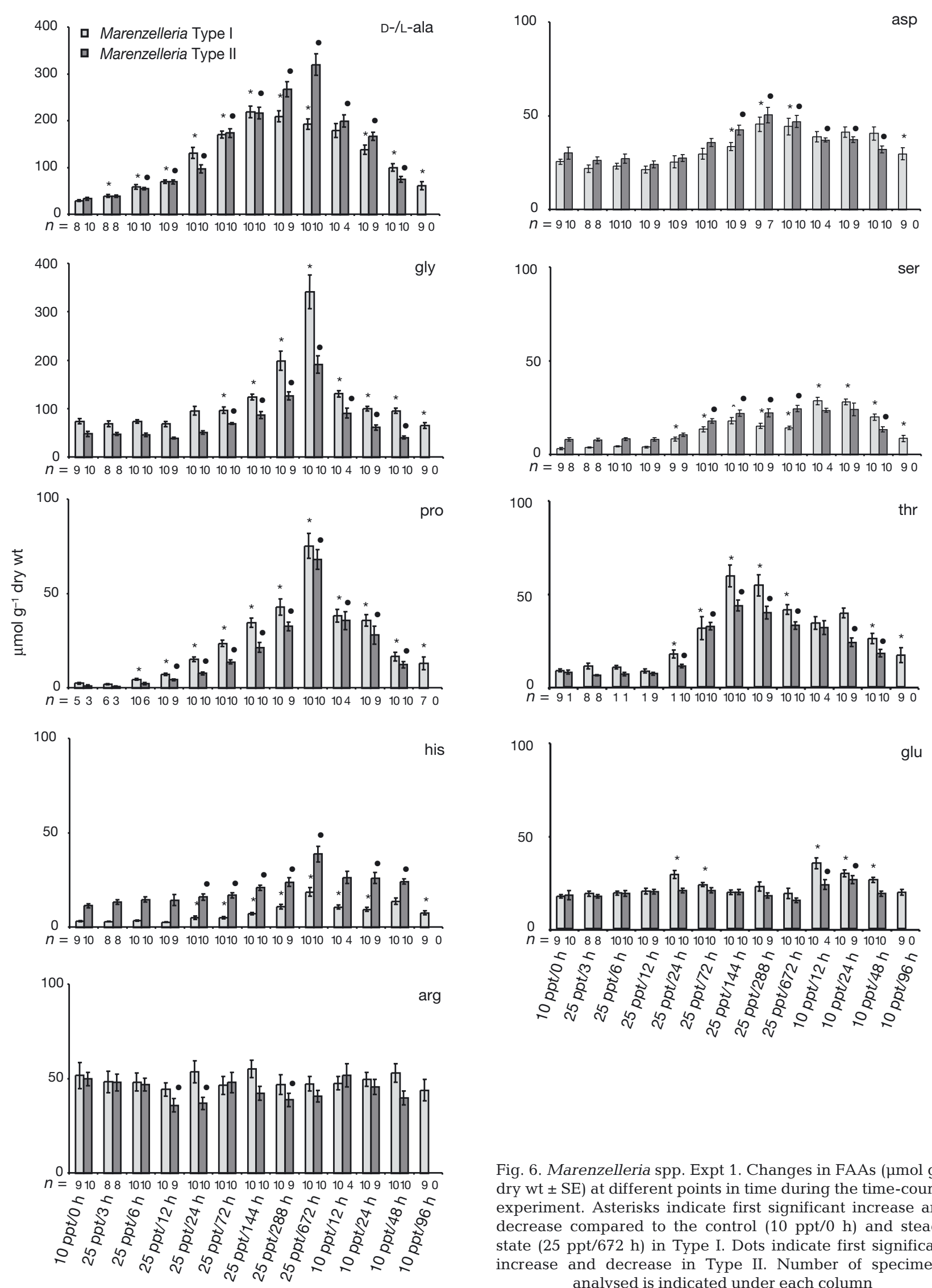

Fig. 6. Marenzelleria spp. Expt 1. Changes in FAAs $\left(\mu \mathrm{mol} \mathrm{g} \mathrm{g}^{-1}\right.$ dry wt $\pm \mathrm{SE}$ ) at different points in time during the time-course experiment. Asterisks indicate first significant increase and decrease compared to the control $(10 \mathrm{ppt} / 0 \mathrm{~h})$ and steady state $(25 \mathrm{ppt} / 672 \mathrm{~h})$ in Type I. Dots indicate first significant increase and decrease in Type II. Number of specimens analysed is indicated under each column 
When a salinity change was made from the new steady state ( $672 \mathrm{~h} / 25 \mathrm{ppt}$ ) to $10 \mathrm{ppt}$, the level of gly and pro declined very quickly in both sibling species. Especially for Marenzelleria Type II, the concentration of $\mathrm{D}, \mathrm{L}$-ala declined rather fast. After $12 \mathrm{~h}$ in $10 \mathrm{ppt}$, the concentration of D, L-ala had decreased to $93 \%$ of its previous level in Marenzelleria Type I and to $62 \%$ in Type II (Fig. 6). Glu and ser are the only 2 amino acids that rise in concentration after dilution of the environmental water. For a period of $24 \mathrm{~h}$, the concentration of glu was much higher in both sibling species, while ser increased only in Type I compared to the original salinity $(25 \mathrm{ppt})$. Then, $48 \mathrm{~h}$ after the salinity change from 25 to $10 \mathrm{ppt}$, the total pool of FAAs was $50 \%$ of the control value (672 h/25 ppt) in Type I and $35 \%$ in Type II. Altogether, the sibling species seemed to react more similarly towards a salinity decrease from 25 to $10 \mathrm{ppt}$ than towards an increase from 10 to $25 \mathrm{ppt}$.

Expt 1 has shown a specific function of ala in connection with hyperosmotic stress. L-ala and D-ala were recorded together in the time-course experiment. A separate Expt 2 was carried out to establish whether D-ala is found in the amino acid pool of Marenzelleria spp. By 2 independent methods, D-ala was found in both Marenzelleria Type I and Type II. Both methods delivered almost identical results for D-ala. HPLC values are slightly higher for L-ala than results obtained by the optical test (Fig. 7). However, this does not seem to be a particularly important aspect in the context of this paper. The amount of D-ala in this experiment was 35 or $32 \%$ of the total alanine (D + L) amount in Marenzelleria Type I, and 26 or $19 \%$, in Type II. The total amount of ala ( $\mathrm{D}+\mathrm{L})$ determined in Expt 2 corresponds to the value from Expt 1 for the time spans of $24 \mathrm{~h}$ (at $25 \mathrm{ppt}$ ) to $72 \mathrm{~h}$ (at $25 \mathrm{ppt}$ ).

\section{DISCUSSION AND CONCLUSION}

\section{Genetic and ecological diversity}

Estuaries characterised by low and fluctuating salinities are also subjected to variations in other factors such as $\mathrm{pH}$, temperature, dissolved oxygen and particulate loadings. However, salinity seems to represent the environmental factor that best explains the distribution of Marenzelleria spp. in the Elbe estuary, although the influence of other abiotic factors cannot be ruled out.

Both Marenzelleria species are hyperosmoregulators at below $\sim 10$ ppt and osmoconformers at above $\sim 10 \mathrm{ppt}$ salinity (Bastrop et al. 1997). Marenzelleria Type I prevails in the Elbe estuary at salinity fluctuations within the osmoconformal range (Stn 5; Fig. 1), while Type II, together with $4 \mathrm{~F}_{1}$-hybrids, was found mainly in the

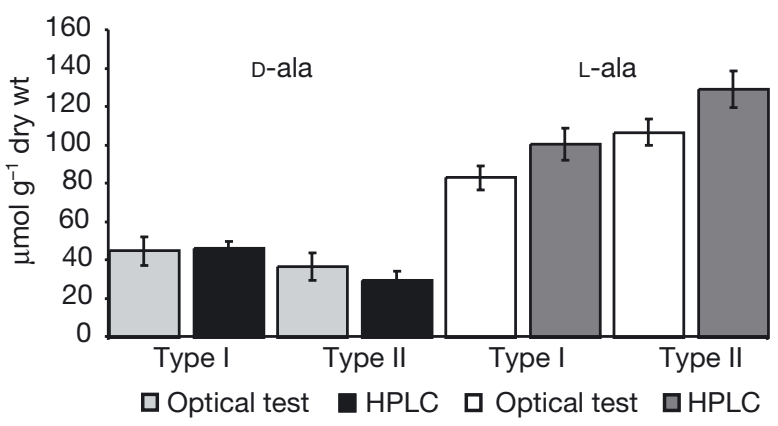

Fig. 7. Marenzelleria spp. Expt 2. Determination of D-alanine (black and light grey columns) and L-alanine (white and dark grey columns) with both the optical test and HPLC after $36 \mathrm{~h}$ in $25 \mathrm{ppt}_{i}$ mean $\left(\mu \mathrm{mol} \mathrm{g}{ }^{-1}\right.$ dry $\left.\mathrm{wt}\right) \pm \mathrm{SE}_{i} \mathrm{n}=5$

hypoosmotic range. Between those 2 ranges, there is an area with salinity fluctuations in the hypo-isoosmotic range in which both sibling species occur sympatrically (Stn 4). On the Atlantic coastline of the US, the area of origin of the Marenzelleria, the 2 sibling species have never been found to occur sympatrically (Röhner et al. 1996b, Bastrop et al. 1997, 1998).

The population of Marenzelleria Type II in the salinity gradient of the Ogeechee River estuary corresponds largely to the Marenzelleria Type II found in the Elbe estuary (Dörjes \& Howard 1975). In all of our studies Marenzelleria Type I was mainly found at higher salinities, whereas Type II prefers oligo- to mesohaline biotopes (Table 1 in Bastrop et al. 1997).

The $\mathrm{F}_{1}$-hybrids are only found in the oligohaline environment (hyperosmotic osmoregulation) of the Elbe estuary. In the detailed work on hybridisation of marine animals, Gardner (1997) did not mention any example of hybridisation among polychaetes. Therefore the existence of hybrids of the Marenzelleria sibling species in the Elbe River is very remarkable.

In order to interpret the distribution of the Marenzelleria sibling species in the Elbe estuary, it is important to look into reproduction as well. During the reproduction phase of Marenzelleria spp., the gametes of numerous spawning individuals are released simultaneously into water. The larvae of Marenzelleria spp. have a planktonic phase lasting several weeks. Sometimes several million larvae per cubic metre were found (Bochert 1997). Juvenile worms also have been found in the plankton (George 1966, Dauer et al. 1980, 1982, Bochert \& Bick 1995). Accordingly, place of reproduction and place of benthic life of the adults examined in the present paper do not necessarily have to be identical. The influence of salinity on the gametogenesis and larval development has been examined in detail for Marenzelleria Type II (Bochert 1997). A salinity of $10 \mathrm{ppt}$ proved favourable for gametal growth, whereas 
$\geq 25$ und $\leq 5 \mathrm{ppt}$ affected it negatively. One-setiger larvae were unable to complete their development to metamorphosis at salinities $<5$ ppt. Metamorphosis to benthic life was possible at salinities between 10 and 20 ppt. Due to this reproduction strategy one could expect that both Marenzelleria species are, in principle, able to colonise the entire Elbe estuary.

Clarke's (Chow \& Clarke 2000) model of the distribution of a species in relation to an abiotic environmental variable describes 3 ranges: range predicted from physiological tolerance $>$ actual range $>$ reproduction range. In line with this model, both sibling species of Marenzelleria do not fully exhaust their physiological tolerance. The results shown here regarding the distribution of Marenzelleria spp. in the Elbe estuary are merely a snap-shot of the 'actual range', since due to the mobility of the larvae and juveniles no statement can be made regarding the 'reproductive range'.

Nevertheless, temperature must also be taken into consideration, since it influences salinity tolerance (Kinne 1971). This leads to the conclusion that the distribution of the Marenzelleria species in the Elbe estuary are certainly also influenced by changing seasons. Seasonal effects play a role in spawning behaviour as well. As yet, it was assumed that Marenzelleria Type I (spring) and Type II (autumn) reproduce at different times (Bochert 1997). However, the existence of hybrids in the Elbe estuary indicates at least partially an overlap of reproduction times.

In total, salinity as an environmental factor plays an important part in the distribution of the Marenzelleria species. In principle, the distribution of sibling species in the Elbe estuary indicates that Type I tolerates salinity fluctuations in the osmoconformic range ( $\geq 10 \mathrm{ppt}$ ) better than Marenzelleria Type II. For the oligohaline range, however, the opposite seems to hold true.

The salinity-related distribution of the mussels Mytilus trossulus and Mytilus edulis in the areas where Baltic Sea and North Sea meet (Varvio et al. 1988, Väinölä \& Hvilsum 1991) parallels the distribution of Marenzelleria sibling species in the Baltic Sea and North Sea as well as in the Elbe estuary.

After a comprehensive comparison of the 2 mussel species and their hybrids on an organism level, Gardner \& Thompson (2001) suggest differences between the taxa. Their distributional differences are likely to occur at cellular or biochemical levels, rather than reflecting a difference in energy balance between the taxa.

\section{Free amino acids and enzyme activities}

Jürss et al. (1999) have suggested that the values of enzyme activities under saturating conditions may be as a suitable starting point for a comprehensive analy- sis of evolutionary adaptation in Marenzelleria spp. For pelagic chaetognatha, nemerteans and annelids (Polychaeta), significant correlations between the metabolic rate $\left(\mathrm{O}_{2}\right.$ consumption) and $\mathrm{CS}$ activities have been found (Thuesen \& Childress 1993a,b). The activities of $\mathrm{ODH}$, as an indicator of the anaerobic potential, and CS lead to the conclusion that the physiological processes in Marenzelleria Types I and II function within the same range of ATP synthesis capacity.

The findings for GDH, GPT and AAT show that Marenzelleria Type I has generally a higher level of activity than Type II. For GPT, this has already been established in 2 previous experiments (Jürss et al. 1999). All 3 enzymes can be involved in transdeamination. Transdeamination is the primary mechanism for catabolism of amino acids (AAs), e.g. in fish the amino group of a variety of AAs is transferred to $\alpha$-ketoglutarate to form glu, which is then deaminated by glutamate dehydrogenase (Jürss \& Bastrop 1995). Regarding invertebrates, the importance of this metabolic process is not as universal as for vertebrates (Bishop 1976, Bishop et al. 1994). However, for the mussel species Mya arenaria indications of functional transdeamination have been reported (Moyes et al. 1985). Findings for the polychaete Arenicola marina (Reitze et al. 1989) suggest that transdeamination plays an important role - at least in these animals. This transdeamination can support ammoniogenesis, but also the synthesis of L-ala and asp. Experiments with the transaminase inhibitor aminooxyacetate (AOA) have shown that aminotransferases, especially GPT, play a vital role in the qualitative composition of the total AA pool in connection with the salinity-related rise of FAAs in Geukensia demissa (Bishop et al. 1981, 1994) and A. marina (Reitze et al. 1989).

In general, from the high constitutive activity level of the enzymes involved in metabolism it could be concluded that, within salinity fluctuations in the osmoconformal range, Marenzelleria Type I can carry out cell vollume regulation faster than Type II. On the other hand, Type I has a disadvantage in comparison to Type II at the oligohaline range. This is in line with the argumentation of the Long Island Sound model of selection at the Lap (leucine amino peptidase) locus for blue mussels (Mytilus edulis; Hilbish et al. 1982, Hilbish \& Koehn 1985, Gardner \& Kathiravetpillai 1997). This mussel experiences Lap-genotype-dependent mortality related to local salinity variation. The differences in mortality arise from higher activities of the Lap94 allozyme compared with the other Lap allozyme. Mussels carrying copies of the Lap94 allele can accumulate cellular FAAs faster than mussels with other alleles, but the same mussels also lose cellular nitrogen at faster rates (Hilbish et al. 1982). Depending on salinity, Lap 94 means either a selective advantage or disadvantage. 
When interpreting the FAA changes in Marenzelleria, it must be taken into consideration that only values for whole individuals (cells + blood + coelomic fluid) are available. The fact that the AA concentration is reduced when salinity is decreased from 25 to $10 \mathrm{ppt}$ could be related to metabolism, protein synthesis, or the release of AAs into the environment. In ecophysiological terms, it is important to note that the time course of the FAA changes is relevant, since at the beginning and end of the acclimation period both Marenzelleria sibling species show roughly the same total concentration of FAAs. It must also be noted that arg is a non-compatible osmolyte (Clarke 1975, Yancey 1994) that has no primary (direct) function during salinity acclimation. Phosphoarginine plays an important role in the regeneration of ATP. The arginine kinase catalyses the adjustment in both directions of the equilibrium between arg + ATP and phosphoarginine $+\mathrm{ADP}+\mathrm{H}^{+}$. Arg is present at a high and stable concentration. Out of 10 enzymes measured, arginine kinase shows the highest activity in both Marenzelleria sibling species (Jürss et al. 1999).

As in a number of other invertebrates (Henry 1995), ala, gly and pro are the most important, well-known organic osmolytes for cell vollume regulation during hyperosmotic stress. In the initial phase after salinity change from 10 to $25 \mathrm{ppt}$, D,L-ala has the most important function in both Marenzelleria species. As early as $3 \mathrm{~h}$ after transfer, Marenzelleria Type I shows a significant rise in $\mathrm{D}, \mathrm{L}$-ala, followed by a significant increase in pro after $6 \mathrm{~h}$. The first significant increases of D,L-ala and of pro in Marenzelleria Type II emerge only after 6 and 12 h, respectively. Gly levels accumulate slowly in both species compared to the former 2 AAs. Significantly increased amounts do not occur until $72 \mathrm{~h}$ after the change.

Because AA accumulated at very different rates, it has to be noted that the time course of a single AA is not necessarily correlated with the time course of the whole FAA pool. The amount of total FAAs is of clear ecophysiological relevance in acclimation to a new salinity.

It has been established in one field study and 3 laboratory experiments that Marenzelleria Type I shows a higher level of GPT activity than Type II (1.88- vs 1.41fold, Jürss et al. 1999; 1.74-vs 1.96-fold, present study). This means a higher ala synthesis capacity of Type I and could be the reason behind the ecologically relevant, quick rise in ala during the initial phase of hyperosmotic stress.

GPT catalyses the synthesis of L-ala, which could be transferred to D-ala in one step by alanine racemase (Reitze et al. 1989, Low et al. 1996). GPT is essential for the steady-state concentrations of D- and L-ala. In the ribbed mussel Geukensia demissa, it has been shown by inhibition with AOA that the ala production was transaminase dependent (Bishop et al. 1994). After hypoosmotic shock, the quantitative reduction of L-ala was almost completely inhibited by AOA in the polychaete Arenicola marina (Reitze et al. 1989).

Two diagnostic GPT loci exist in both Marenzelleria species (Jürss et al. 1999). Future analysis should establish how far the different GPT activities have their origin in differences in enzyme kinetics and/or in expression of the genes. Oysters (Crassostrea virginica) from the Atlantic Ocean accumulate more glycine betaine than oysters from Chesapeake Bay after hyperosmotic stress (Dragolovich 1994). Differences in betaine dehydrogenase and choline dehydrogenase kinetics between the 2 oyster populations seem to be responsible for the observed differences in glycine betaine recovery patterns (Perrino \& Pierce 2000a,b).

In terms of cell vollume regulation, euryhaline marine invertebrates generally tend to tolerate declining salinities more easily than elevating salinities (Gilles 1979). Furthermore, the reduction of the FAA pool is almost identical in both Marenzelleria sibling species. Due to its higher level in GPT activity, Type I was expected to display a faster decline of ala, while the opposite was measured. It is also remarkable that gly, with its relatively low turnover (Bishop et al. 1994), declines fastest and to the highest extent. In this context, it has to be taken into consideration that the rising level of the FAAs during rising salinity is due to metabolic reactions (proteolysis, transdeamination, de novo synthesis), while during reduction of salinity, the change in FAAs is mainly due to catabolism and excretion into the environment (Bayne 1975, Livingstone et al. 1979, Gilles 1979, Reitze et al. 1989, Ballantyne \& Chamberlin 1994).

For euryhaline invertebrates, the excretion of $\mathrm{NH}_{3}$ / $\mathrm{NH}_{4}{ }^{+}$and AAs increases in parallel to the reduction of salinity (Bayne 1975, Gilles 1979, Reitze et al. 1989, Ballantyne \& Chamberlin 1994). In contrast to the general tendency of other non-essential AAs, glu temporarily rises after a change of salinity from 25 to 10 ppt in both Marenzelleria species, while ser levels increased temporarily in Type I only. Glu could be produced by degradation of pro, while ser could derive from gly (Bishop et al. 1994).

To summarise, it can be concluded that with regard to the time course of the cell vollume regulation by means of FAAs, Marenzelleria Type I adapts better to salinity fluctuations in the osmoconformal range (>10 ppt) than Marenzelleria Type II. Together with the species-specific distribution of the Marenzelleria sibling species in the salinity gradient of the Elbe River, the physiological findings can, at least in part, explain the spatial distribution of sibling species Types I and II in the area of origin (North America) and in the colonised habitats of the North and Baltic Seas. 
Acknowledgements. We gratefully acknowledge the Amt für Strom- und Hafenbau, Freie und Hansestadt Hamburg, for their supporting role in collecting samples in the Elbe River estuary. The authors wish to express their thanks to K. Schwandt for technical assistance. We are indebted to S. Bremer, S. Görs and S. Lembcke for assistance in the HPLC measurements. We also thank C. Peters for her help in translating and $\mathrm{M}$. Hagemann for correcting the manuscript. The authors thank the reviewers for their comments and suggestions.

\section{LITERATURE CITED}

Arndt EA (1989) Ecological, physiological and historical aspects of brackish water fauna distribution. In: Ryland JS, Tyler PA (eds) Reproduction, genetics and distributions of marine organisms. Proc 23rd Eur Mar Biol Symp, School of Biol Sci, Univ of Wales, Swansea, Int Symp Ser. Olsen \& Olsen, Fredensborg, p 327-338

Ayala FJ, Powell JR (1972) Allozymes as diagnostic characters of sibling species of Drosophila. Proc Natl Acad Sci USA 69:1094-1096

Ballantyne JS, Chamberlin ME (1994) Regulation of cellular amino acid levels. In: Strange K (ed) Cellular and molecular physiology of cell vollume regulation. CRC Press, Boca Raton, FL, p 111-132

Bastrop R, Röhner M, Jürss K (1995) Are there 2 species of the polychaete genus Marenzelleria in Europe? Mar Biol 121: 509-516

Bastrop R, Röhner M, Sturmbauer C, Jürss K (1997) Where did Marenzelleria spp. (Polychaeta: Spionidae) in Europe come from? Aquat Ecol 31:119-136

Bastrop R, Jürss K, Sturmbauer C (1998) Cryptic species in a marine polychaete and their independent introduction from North America to Europe. Mol Biol Evol 15:97-103

Bayne BL (1975) Aspects of physiological condition in Mytilus edulis L., with special reference to the effects of oxygen tension and salinity. In: Barnes H (ed) Proc 9th Eur Mar Biol Symp. Aberdeen University Press, Aberdeen, p 213-238

Bick A, Burckhardt R (1989) First record of Marenzelleria viridis (Polychaeta, Spionidae) in the Baltic Sea, with a key to the Spionidae of the Baltic Sea. Mitt Zool Mus Berl 65: $237-247$

Bick A, Zettler ML (1997) On the identity and distribution of two species of Marenzelleria in Europe and North America. Aquat Ecol 31:137-148

Bishop SH (1976) Nitrogen metabolism and excretion: regulation of intracellular amino acid concentrations. In: Witey M (ed) Estuarine processes, Vol 1. Academic Press, New York, p 414-431

Bishop SH, Greenwalt DE, Burcham JM (1981) Amino acid cycling in ribbed mussel tissues subjected to hyperosmotic shock. J Exp Zool 215:277-287

Bishop SH, Greenwalt DE, Kapper MA, Paynter KT, Ellis LL (1994) Metabolic regulation of proline, glycine, and alanine accumulation as intracellular osmolytes in ribbed mussel gill tissue. J Exp Zool 268:151-161

Bochert R (1996) Untersuchungen zur Reproduktionsbiologie von Marenzelleria viridis (Polychaeta, Spionidae) in einem flachen Küstengewässer der südlichen Ostsee. $\mathrm{PhD}$ thesis, University of Rostock

Bochert R (1997) Marenzelleria viridis (Polychaeta: Spionidae): a review of its reproduction. Aquat Ecol 31:163-175

Bochert R, Bick A (1995) Reproduction and larval development of Marenzelleria viridis (Polychaeta: Spionidae). Mar Biol 123:763-773
Chow SL, Clarke A (2000) Stress and the geographic distribution of marine and terrestrial animals. In: Storey KB, Storey JM (eds) Cell and molecular responses to stress, Vol 1. Elsevier, Amsterdam, p 41-54

Clarke B (1975) The contribution of ecological genetics to evolutionary theory: detecting the direct effects of natural selection on particular polymorphic loci. Genetics 79:101-113

Dauer DM, Tourtellotte GH, Barker HR (1980) Nocturnal swimming of Scolecolepides viridis (Polychaeta: Spionidae). Estuaries 3:148-149

Dauer DM, Ewing RM, Sourbeer JW, Harlan WT, Stokes TL (1982) Nocturnal movements of the macrobenthos of the Lafayette River, Virginia. Int Rev Gesamten Hydrobiol 67: 761-775

Dörjes J, Howard JD (1975) Estuaries of the Georgia coast, USA: sedimentology and biology. IV. Fluvial-marine transition indicators in an estuarine environment, Ogeechee River-Ossabaw Sound. Senckenb Marit 7:137-179

Dragolovich J (1994) Dealing with salt stress in animal cells: the role and regulation of glycine betaine concentrations. J Exp Zool 268:139-144

Elliott M, Kingston PF (1987) The sublittoral benthic fauna of the estuary and Firth of Forth, Scotland. Proc R Soc Edinb Sect B (Biol Sci) 93B:449-465

Essink K, Kleef HL (1993) Distribution and life cycle of the North American spionid Marenzelleria viridis (Verrill, 1873) in the Ems estuary. Neth J Aquat Ecol 27:237-246

Gardner JPA (1997) Hybridization in the sea. Adv Mar Biol $31: 2-79$

Gardner JPA, Kathiravetpillai G (1997) Biochemical genetic variation at a leucine aminopeptidase (LAP) locus in blue (Mytilus galloprovincialis) and greenshell (Perna canaliculus) mussel populations along a salinity gradient. Mar Biol 128:619-625

Gardner JPA, Thompson RJ (2001) The effects of coastal and estuarine conditions on the physiology and survivorship of the mussels Mytilus edulis, $M$. trossulus and their hybrids. J Exp Mar Biol Ecol 265:119-140

George JD (1966) Reproduction and early development of the spionid polychaete, Scolecolepides viridis (Verrill). Biol Bull (Woods Hole) 130:76-93

Gilles R (1975) Mechanisms of the ion and osmoregulation. In: Kinne $\mathrm{O}$ (ed) Marine ecology: a comprehensive, integrated treatise on life in oceans and coastal waters, Vol 2 , Part 1. Wiley, London, p 259-347

Gilles R (1979) Intracellular organic osmotic effectors. In: Gilles R (ed) Mechanisms of osmoregulation in animals: maintenance of cell volume. Wiley, Chichester, p 111-154

Görs S (2002) Chemische Charakterisierung von gelöstem und partikulärem organischen Material im Trophiegradienten der Darß-Zingster Boddenkette unter besonderer Berücksichtigung von Proteinen und Aminosäuren. PhD thesis, University of Rostock

Graßl M, Supp M (1985) D-Alanine. In: Bergmeyer HU, Bergmeyer J, Graßl M (eds) Methods of enzymatic analysis, Vol VIII, 3rd edn. VCH Verlagsgesellschaft, Weinheim, p 336-340

Henry RP (1995) Nitrogen metabolism and excretion for cell vollume regulation in invertebrates. In: Walsh PJ, Wright $\mathrm{P}$ (eds) Nitrogen metabolism and excretion. CRC Press, Boca Raton, FL, p 63-73

Hilbish TJ, Koehn RK (1985) Dominance in physiological phenotypes and fitness at an enzyme locus. Science 229: $52-54$

Hilbish TJ, Daeton LE, Koehn RK (1982) Effect of an allozyme polymorphism on regulation of cell volume. Nature 298: 688-689 
Hohendorf K (1963) Der Einfluß der Temperatur auf die Salzgehaltstoleranz und Osmoregulation von Nereis diversicolor O. F. Muell. Kiel Meeresforsch 19:196-218

Jürss K, Bastrop R (1995) Amino acid metabolism in fish. In: Hochachka PW, Mommsen TP (eds) Biochemistry and molecular biology of fishes, Vol 4. Elsevier, Amsterdam, p 159-189

Jürss K, Röhner M, Bastrop R (1999) Enzyme activities and allozyme polymorphism in 2 genetic types (or sibling species) of the genus Marenzelleria (Polychaeta: Spionidae) in Europe. Mar Biol 135:489-496

Kinne O (1971) 4. Salinity. 4.3. Animals. 4.31. Invertebrates. In: Kinne O (ed) Marine ecology: a comprehensive, integrated treatise on life in oceans and coastal waters, Vol 1, Part 2. Wiley, London, p 820-995

Kolding S (1985) Genetic adaptation to local habitats and speciation processes within the genus Gammarus (Amphipoda: Crustacea). Mar Biol 89:249-255

Livingstone DR (1991) Origins and evolution of pathways of anaerobic metabolism in the animal kingdom. Am Zool 31: 522-534

Livingstone DR, Widdows J, Fieth P (1979) Aspects of nitrogen metabolism of the common mussel Mytilus edulis: adaptation to abrupt and fluctuating changes in salinity. Mar Biol 53:41-55

Low WP, Ong WT, Ip YK (1996) Different physiological functions of free D- and L-alanine in three body parts of the intertidal sipunculid Phascolosoma arcuatum. J Comp Physiol B Biochem Syst Environ Physiol 165:558-564

Moyes CD, Moon TW, Ballantyne JS (1985) Glutamate catabolism in mitochondria from Mya arenaria mantle: effects of $\mathrm{pH}$ on the role of glutamate dehydrogenase. J Exp Zool 236:293-301

Nei M (1972) Genetic distance between populations. Am Nat 106:283-292

Nei M (1978) Estimation of average genetic heterozygosity and genetic distance from a small number of individuals. Genetics 23:341-369

Nimura N, Kinoshita T (1986) o-Phthalaldehyde-n-acetyl-Lcysteine as a chiral derivatization reagent for liquid chromatographic optical resolution of amino acid enantiomers and its application to conventional amino acid analysis. J Chromatogr 332:169-177

Oglesby LC (1978) Salt and water balance. In: Mill PJ (ed) Physiology of annelids. Academic Press, London, p 555-658

Peng KW, Chew SF, Ip YK (1994) Free amino acids and cell vollume regulation in the sipunculid Phascolosoma arcuatum. Physiol Zool 67:580-597

Perrino LA, Pierce SK (2000a) Betaine aldehyde dehydrogenase kinetics partially account for oyster population differences in glycine betaine synthesis. J Exp Zool 286: 238-249

Perrino LA, Pierce SK (2000b) Choline dehydrogenase kinetics contribute to glycine betaine regulation differences in
Chesapeake Bay and Atlantic oysters. J Exp Zool 286: 250-261

Reitze M, Schöttler U, Luftmann H (1989) Alanine metabolism of the lugworm Arenicola marina L. (Annelida: Polychaeta) during adaptation to reduced salinity. Comp Biochem Physiol B 93:689-696

Röhner M, Bastrop R, Jürss K (1996a) Genetic differences between two allopatric populations (or sibling species?) of the polychaete genus Marenzelleria in Europe. Comp Biochem Physiol B 114:185-192

Röhner M, Bastrop R, Jürss K (1996b) Colonization of Europe by two American genetic types or species of the genus Marenzelleria (Polychaeta: Spionidae). An electrophoretic analysis of allozymes. Mar Biol 127:277-287

Schiedek D (1997a) Marenzelleria viridis (Verrill, 1873) (Polychaeta), a new benthic species within European coastal waters. Some metabolic features. J Exp Mar Biol Ecol 211: 85-101

Schiedek D (1997b) Marenzelleria cf. viridis (Polychaeta: Spionidae) - ecophysiological adaptations to a life in the coastal waters of the Baltic Sea. Aquat Ecol 31:199-210

Schiedek D (1999) Ecophysiological capability of Marenzelleria populations inhabiting North Sea estuaries: an overview. Helgol Meeresunters 52:373-382

Schiedek D, Vogan C, Hardege J, Bentley M (1997) Marenzelleria cf. wireni (Polychaeta: Spionidae) from the Tay estuary. Metabolic response to severe hypoxia and hydrogen sulphide. Aquat Ecol 31:211-222

Stryer L (1996) Biochemie, 4th edn. Spektrum Akad Verlag, Heidelberg

Thuesen EV, Childress JJ (1993a) Enzymatic activities and metabolic rates of pelagic chaetognaths: lack of depthrelated declines. Limnol Oceanogr 38:935-948

Thuesen EV, Childress JJ (1993b) Metabolic rates, enzyme activities and chemical compositions of some deep-sea pelagic worms, particularly Nectonemertes mirabilis (Nemertea: Hoplonemertinea) and Poeobius meseres (Annelida: Polychaeta). Deep-Sea Res Part I 40:937-951

Väinölä R, Hvilsom MM (1991) Genetic divergence and a hybrid zone between Baltic and North Sea Mytilus populations (Mytilidae: Mollusca). Biol J Linn Soc 43:127-148

Varvio SL, Koehn RK, Väinölä R (1988) Evolutionary genetics of the Mytilus edulis complex in the North Atlantic region. Mar Biol 98:51-60

Webb P, Wooldridge T, Schlacher T (1997) Osmoregulation and spatial distribution in four species of mysid shrimps. Comp Biochem Physiol A Comp Physiol 117A:427-431

Williamson DH (1985) L-Alanine. In: Bergmeyer HU, Bergmeyer J, Graßl M (eds) Methods of enzymatic analysis, Vol VIII, 3rd. edn. VCH Verlagsgesellschaft, Weinheim, p 341-344

Yancey PH (1994) Compatible and counteracting solutes. In: Strange K (ed) Cellular and molecular physiology of cell vollume regulation. CRC Press, Boca Raton, FL, p 81-109 
Appendix 1. Marenzelleria spp. Number of individuals sampled $(N)$ and genotype frequencies in 4 populations in the North Sea and Baltic Sea

\begin{tabular}{|c|c|c|c|c|c|c|c|c|c|}
\hline $\begin{array}{l}\text { Locus } \\
\quad \text { Genotype }\end{array}$ & $\begin{array}{l}\text { Type I } \\
\text { Elbe }\end{array}$ & $\begin{array}{c}\text { Type I } \\
\text { Ringkobing } \\
\text { Fjord }\end{array}$ & $\begin{array}{l}\text { Type II } \\
\text { Elbe }\end{array}$ & $\begin{array}{c}\text { Type II } \\
\text { Darss-Zingst } \\
\text { Bodden Chain }\end{array}$ & $\begin{array}{l}\text { Locus } \\
\quad \text { Genotype }\end{array}$ & $\begin{array}{l}\text { Type I } \\
\text { Elbe }\end{array}$ & $\begin{array}{c}\text { Type I } \\
\text { Ringkobing } \\
\text { Fjord }\end{array}$ & $\begin{array}{l}\text { Type II } \\
\text { Elbe }\end{array}$ & $\begin{array}{c}\text { Type II } \\
\text { Darss-Zingst } \\
\text { Bodden Chain }\end{array}$ \\
\hline$I D H^{*}$ & & & & & G3PDH $^{*}$ & & & & \\
\hline$(\mathrm{N})$ & 212 & 70 & 200 & 70 & $(\mathrm{~N})$ & 123 & 70 & 136 & 70 \\
\hline $2-2$ & 0.566 & 0.571 & - & - & $1-3$ & - & - & 0.007 & - \\
\hline $2-3$ & 0.406 & 0.300 & - & - & $3-3$ & 0.317 & 0.314 & 0.919 & 0.857 \\
\hline $3-3$ & 0.028 & 0.129 & - & - & $3-4$ & - & - & 0.066 & 0.129 \\
\hline $4-4$ & - & - & 1 & 1 & $4-4$ & - & - & - & 0.014 \\
\hline $7-4$ & & & & 1 & $3-5$ & 0.504 & 0.514 & 0.007 & - \\
\hline$A A T-I^{*}$ & & & & & $5-5$ & 0.179 & 0.171 & - & - \\
\hline$(N)$ & 213 & 70 & 200 & 70 & $G A P D H^{*}$ & & & & \\
\hline $1-2$ & - & 0.014 & 0.010 & - & $(\mathrm{N})$ & 213 & 70 & 201 & 70 \\
\hline $2-2$ & 1 & 0.986 & 0.990 & 1 & $1-1$ & 1 & 1 & - & - \\
\hline & & & & & $2-2$ & - & - & 1 & 1 \\
\hline $\begin{array}{l}\boldsymbol{A A I - \boldsymbol { I } ^ { * }} \\
\quad(\mathrm{N})\end{array}$ & 211 & 69 & 182 & 70 & $O D H-1^{*}$ & & & & \\
\hline $1-3$ & - & - & 0.011 & 0.014 & $(\mathrm{~N})$ & 181 & 69 & 173 & 70 \\
\hline $3-3$ & - & - & 0.967 & 0.957 & $2-3$ & - & - & 0.040 & - \\
\hline $3-4$ & 0.081 & 0.029 & 0.022 & $\begin{array}{l}0.951 \\
0.029\end{array}$ & $3-3$ & 0.724 & 0.493 & 0.931 & 0.971 \\
\hline $4-4$ & 0.919 & 0.971 & - & - & $3-4$ & 0.155 & 0.304 & 0.017 & 0.029 \\
\hline & & & & - & $3-5$ & 0.039 & 0.130 & 0.012 & - \\
\hline$A K^{*}$ & & & & & $4-4$ & 0.055 & 0.043 & - & - \\
\hline$(\mathrm{N})$ & 202 & 70 & 201 & 70 & $4-5$ & 0.017 & 0.029 & - & - \\
\hline $1-4$ & - & - & 0.005 & - & $5-5$ & 0.011 & - & - & - \\
\hline $1-7$ & - & - & 0.005 & - & $M D H-I^{*}$ & & & & \\
\hline $3-3$ & 0.990 & 0.971 & - & - & $(\mathrm{N})$ & 213 & 70 & 201 & 70 \\
\hline $3-6$ & 0.010 & 0.029 & - & - & $1-1$ & 1 & 1 & 0.995 & 0.971 \\
\hline $4-4$ & - & - & 0.527 & 0.557 & $1-2$ & - & - & 0.005 & 0.029 \\
\hline $4-7$ & - & - & 0.378 & 0.286 & $M D H-I I^{*}$ & & & & \\
\hline $4-8$ & - & - & 0.015 & 0.014 & $(\mathrm{~N})$ & 211 & 70 & 201 & 70 \\
\hline $4-9$ & - & - & 0.015 & 0.029 & $2-2$ & - & - & 0.995 & 1 \\
\hline $4-10$ & - & - & 0.005 & 0.014 & $2-5$ & 1 & 1 & 0.005 & - \\
\hline $7-7$ & - & - & 0.040 & 0.086 & $\boldsymbol{A P K}^{*}$ & & & & \\
\hline $7-9$ & - & - & 0.005 & 0.014 & $(\mathrm{~N})$ & 211 & 70 & 201 & 70 \\
\hline $9-10$ & - & - & 0.005 & - & $1-1$ & - & - & 1 & 1 \\
\hline & & & & & $2-2$ & 1 & 1 & - & - \\
\hline
\end{tabular}

Editorial responsibility: Otto Kinne (Editor), Oldendorf/Luhe, Germany
Submitted: June 16, 2003; Accepted: November 11, 2003 Proofs received from author(s): April 14, 2004 